\title{
Dynamic links between economic growth, institutions, fiscal policy and stock market development
}

\author{
Ghulam Rasool Madni \\ The University of Lahore, Pakistan \\ Correspondence author email: ghulam.rasool@econ.uol.edu.pk
}

\begin{abstract}
Economic growth is a most crucial factor that plays its role to improve the living standards in a country. But there is no consensus about the variables explaining the economic growth of economies. This paper is an attempt to explore the impact of institutional quality, instruments of fiscal policy, and stock market development on economic growth for a small developing economy, Pakistan over the time span of 19842016. To determine the long and short run relationship of the variables, Auto Regressive Distributed Lag (ARDL) bounds testing approach to integration is applied. An index of institutional quality is constructed by Principal Component Analysis (PCA) considering twelve institutional indicators given by International Country Risk Guide (ICRG). The findings of the study reveal a positive relationship of public spending, institutional quality and stock market development on economic growth of the country. It is suggested that improvement of institutional quality, productive public spending and efficient financial markets are driving forces for economic prosperity and development of Pakistan.
\end{abstract}

Keywords: Economic growth, Institutions, Stock market, Public spending JEL Classification: B22, C32, Q43

\section{INTRODUCTION}

Economic growth is a vivid and ultimate source for economic development and prosperity which raises an economy's potential GDP and must be sustained in long run to achieve the desired goal of public welfare. Economic growth is a fundamental instrument and indicator for sustainability and development of any economy. In long run, the focus of governments is to foster sustainable economic growth. The sustained growth of any country is helpful to improve living standard of people in many ways like reducing the poverty, enhancing the infrastructure and educational facilities, combating increased inflation, and reducing the external vulnerabilities.

There is no consensus upon determinants of economic growth for an economy. Theoretical and numerical facts reveal that public spending, institutional quality and stock market have a pivotal role for economic growth. It may be observed that no society reaped towering echelon of economic growth without the intervention of government. Economies without interference of government face diverse hue of chaos that freezes their economic growth with passage of time. Government expenditures allow government to reallocation of resources from elite to poor. It is obvious that fiscal policy is a pre-condition to achieve macroeconomic permanence and sustainable economic growth that can have foremost impacts on income generation and poverty alleviation through taxation, optimal revenues generation, public borrowings and public expenditures. Recently, role of public spending got a striking attention of the policy makers and researchers of the subject, especially after financial crisis of 2007. 
Endogenous and Keynesian growth theories proved the significant role of fiscal policy for economic development of an economy. The public spending may be helpful to raise the economic growth by developing the institutions like maintaining the law and order, protection of property rights, control over corruption, provision of public goods, and other social services that may lead to improve the aggregate demand and sustainability of economic growth.

The institutional role in growth route of economies got importance during decade of the 1990's, when two pioneer studies by Knack and Keefer's (1995) "Institutions and Economic Performance", and Mauro's (1995) "Corruption and Growth" were published. By relying on new dimensions of property rights and institutions, these items ushered in a new generation of devoted research to prove importance of institutional framework in economic performance across the countries. Knack and Keefer (1995) considered the data of 97 economies from 1974 to 1989 and concluded that institutional quality is working as a protection of property rights and contract enforcement is an essential difference for investment and growth. In the same way, Mauro (1995) found that the corruption rates have negative association with economic growth and private investment. The other experimental evidence supports these preliminary results. For example, Alesina (1998) and Madni (2017) indicates that institutional quality plays a vital role for growth and this quality of institutions was measured by bureaucracy, corruption, property rights and law \& order.

The effectiveness of unwavering financial markets has been highlighted for prosperity and development of an economy because stability of stock market is considered as a sign of complete macroeconomic execution and performance of an economy. The supporters of stock market are of view that it has a significant role for development of industry and commerce leading to enhance the economic prosperity. Generally, the theoretical discussions deliberate the functions of the stock market in encouraging capital allocation, mobilizing and assembling savings, and engendering information for prospective investments liquidity. It is believed that presence of stable and active stock market can promote economic growth. Schumpeter (1911), Goldsmith (1969), Shaw (1973) and McKinnon (1973) found that financial markets and financial intermediaries play a pivotal role for economic growth and development. According to Levine (1997. p. 691), "to organize the vast literature on finance and economic activity, I break this primary function into five basic functions. Specifically, financial systems: Facilitate the trading, hedging, diversifying, and pooling of risk, allocate resources, monitor managers and exert corporate control, mobilize savings, and facilitate the exchange of goods and services."

Pakistan is a developing country of the world depending on agriculture, industry, manufacturing and remittances. Pakistan has experienced respectable economic growth for more than three decades i.e. up to 1990 . The economy grew over $6 \%$ per annum, on average, but after that economy performed poorly.

Table 1. Economic growth and fiscal variables as percentage of GDP

\begin{tabular}{lccrrc}
\hline \multicolumn{1}{c}{ Variables/ Years } & 1970's & 1980's & 1990's & 2000's & 2011-16 \\
\hline GDP Growth & 5.0 & 7.1 & 4.4 & 4.7 & 4.0 \\
Fiscal Deficit & 8.6 & 5.5 & 7.3 & 4.6 & 6.4 \\
Public Expenditures & 21.9 & 22.3 & 23.2 & 18.8 & 20.2 \\
Current Expenditures & 18.6 & 17.8 & 19.8 & 15.5 & 16.1 \\
Development Expenditures & 3.3 & 4.5 & 3.4 & 3.3 & 4.1 \\
Defense Expenditures & 6.0 & 6.3 & 5.8 & 3.5 & 2.5 \\
\hline
\end{tabular}

Source: The World Bank and Pakistan Economic Survey (Various Issues) 
Wagner's law states that public expenditures' elasticity exceeds well above unity in the early economic growth process. It implies that a country needs more public expenditures for providing social services. In spite of fluctuating trend in public expenditures and fiscal deficit, GDP growth could not be enhanced as compared with preceding decades after 1980's. It can be observed that development expenditures are not strengthened with passage of time and have a stable trend. Current expenditures remained at the priority of state while development expenditures could not gain their importance. Increased fiscal deficits were utilized to finance the current expenditures but they could not contribute in growth process significantly.

The decade of the 1990's remained worst, not due to poor economic performance but also due to poor governance, political instability (during the period of 1988-99, eleven governments were changed resulting in loss of confidence of investors and growth), debt burden (accrued during the period of 1977-88, resulting in annual interest payments made equal to 60 percent of budget and 25 percent for defense, so development expenditures were reduced significantly), and imposed sanctions on Pakistan in the decade of the 1990's relevant to nuclear propagation. During the constitutional period of five years (2008-13), the average GDP growth rate during this period was only three percent, industrial growth was near to zero, investment rate declined to $12.5 \%$ of GDP (lowest in the history of Pakistan), budget deficit was $7 \%$ of GDP on average and public debt became double. Corruption and poor governance were key factors that affected every sector of the economy.

If we have a look on performance of institutions in Pakistan, we come to know that country has very poor development of institutions and rents are extracted by elites by breaches of laws or abuses of institutions as highlighted by Hassan (2002). The performance of institutional indicators of Pakistan is given in the Table 2.

Table 2. Institutional Performance of Pakistan*

\begin{tabular}{lcccccr}
\hline $\begin{array}{l}\text { Years/ } \\
\text { Variables }\end{array}$ & $\begin{array}{c}\text { Voice } \\
\text { and } \\
\text { Accounta- } \\
\text { bility }\end{array}$ & $\begin{array}{c}\text { Political } \\
\text { Stability and } \\
\text { Absence of } \\
\text { Violence }\end{array}$ & $\begin{array}{c}\text { Govern- } \\
\text { ment } \\
\text { Effective- } \\
\text { ness }\end{array}$ & $\begin{array}{c}\text { Regulatory } \\
\text { Quality }\end{array}$ & $\begin{array}{c}\text { Rule of } \\
\text { Law }\end{array}$ & $\begin{array}{c}\text { Control of } \\
\text { Corrup- } \\
\text { tion }\end{array}$ \\
\hline $\mathbf{1 9 9 6 - 2 0 0 0}$ & -0.87 & -1.17 & -0.54 & -0.55 & -0.80 & -0.97 \\
$\mathbf{2 0 0 1 - 2 0 0 5}$ & -1.19 & -1.65 & -0.41 & -0.75 & -0.79 & -0.94 \\
$\mathbf{2 0 0 6 - 2 0 1 0}$ & -0.89 & -2.46 & -0.61 & -0.53 & -0.85 & -0.88 \\
$\mathbf{2 0 1 1 - 2 0 1 5}$ & -0.82 & -2.40 & -0.74 & -0.67 & -0.84 & -0.92 \\
\hline
\end{tabular}

*Values approximately range from -2.5 (weak position) to 2.5 (strong position)

Source: World Governance Indicators

The presented data reveal that institutional performance in Pakistan is very poor and having trend of further deterioration. According to Hassan (2002), there was degeneration of institutions in the country over the past three decades, and the decade of 1990's brought a great degradation of institutions. Poor governance of country excluded the poor people of society in process of decision making and malfunctioning of institutions caused the failure of benefits of rising per capita income to the poor. The increased poverty further weakened the quality of institutions and poor are trapped in the vicious circle of poverty.

The Pakistan Stock Exchange ${ }^{1}$ was demoted to frontier-market status in 2009 after it introduced restrains against sell orders to stanch an investor migration in late 2008. Pakistan's stock market has been on a tear in recent years. The country's main KSE index has gained close to $400 \%$ since 2009, and $40 \%$ in 2016. Pakistan Stock Exchange

\footnotetext{
${ }^{1}$ A merger of Karachi Stock Exchange, Lahore Stock Exchange, Islamabad Stock Exchange
} 
is declared as the best performing in Asia and $5^{\text {th }}$ best performing market in world in 2016 , in spite of multiple economic and social problems of the country. The global stock markets also grew in 2015 but the stock market of Pakistan gained and outstanding performance among the world's largest and most liquid stock markets including china, Hong Kong, India, Japan, Singapore, UK and USA.

The previous numerical facts reveal the volatility in economic growth of Pakistan in different time periods which requires to be studied further. Realizing the importance and effectiveness of institutions, stock market and government spending from literature, it will be much concern of interest to know the impact of public spending, stock market and institutions on economic growth of Pakistan, a core objective of this study. There is hardly any study that has investigated the impact of institutions, stock market and fiscal policy jointly on economic growth of the country.

After introduction, Section 2 outlines the literature review and Section 3 provides theoretical framework. Section 4 has details of data and variables. Methodology and empirical analysis are discussed in Section 5 while Section 6 concludes the chapter.

\section{LITERATURE REVIEW}

Ramadhan, et al. (2016) investigated the role of political stability for economic growth and development in Tanzania by employing Vector Error Correction Model (VECM) for the time span of 1996-2104. It was hypothesized that political stability plays a vital role for economic development and prosperity of any country. To test the unit root, Phillips Perron (PP) and Augmented Dickey Fuller (ADF) were applied and then cointegration was tested. The cointegration test proves the presence of long run relationship among the variables. The findings of the study reveal that political stability has a significant and positive impact on economic growth of Tanzania. It was also concluded that labor force and investment have insignificant positive impact on economic growth of the said country.

Ibrahim and Gadir (2015) examined to find out the motives and determinants affecting the Foreign Direct Investment in Oman covering the time period of 1980 2013. Public spending, trade openness, market size, inflation rate and natural resources are considered to be affecting the FDI. Johansen cointegration and VECM are applied to find the short and long run dynamics of FDI. It was found that natural resources and market size have positive impact on FDI while inflation and trade openness harm the FDI. Moreover, Granger causality results reveal that FDI inflow is due to resource seeking and market seeking motives.

Christie (2011) highlighted various aspects of the relationship between government expenditures and economic growth in the long term. A model has been developed through the application of a general method of moments (GMM) to find the dynamic nature of relation between the variables (government spending, economic growth) for 136 developing and developed countries during the period of 1971 to 2005 . The conclusions of the study indicate that government spending beyond the threshold level affects the growth negatively. The findings of the study indicate that public spending at 26-32\% of GDP is threshold level for developed economies and $33 \%$ of GDP for developing countries. Based on the findings, it was suggested to manage public spending; because 28 developed economies have the public spending more than $30 \%$ of GDP from 2001 to 2005.The expansion of public spending in these economies will have negative impacts on long term growth. The outcomes of research indicate that improving the quality of institutions may improve the economic growth in case of increasing public spending. It was also found that the threshold level of spending 
without imposing serious side effects between production and non-productive spending, which alleviate the potential gain of increased government expenditure.

Benos (2009) disintegrated public revenues and government spending into subcategories and analyzed the impact of each category on GDP growth of 14 European Union economies for the period 1990 to 2006. In this study, public spending on health, recreation, education, housing, culture, economic affairs, religion, defense, public order safety, taxes on wealth, income, capital, imports, production, and fiscal deficit are considered as fiscal variables while private investment, population, secondary education, employment growth, imports and exports are treated as non fiscal variables. Panel data techniques and ordinary least square methods were applied to estimate the results. The empirical analysis reveals that public spending on human capital has not significant effect on economic growth while infrastructure spending affects the economic growth positively. It was also found that taxation affect economic growth negatively while budget deficit has not a clear relation with economic growth.

Glaeser (2004) observed that proposition about the positive impact of institutions on economic growth is ambiguous and variables used to measure the institutional quality is unsuitable for this purpose. He argued that these variables do not measure the quality of institutions which is claimed as constraints in theoretical literature but it is outcome of institutional variables. Author is of view that governance indicators are very volatile that do not reflect the actual position of political environment bit it varies with variation in per capita income. The established empirical relationship between institutions and economic growth in literature was questioned about the instrumental techniques and common measures by author and his collaborators.

Feng (2003) used the pattern of political economy theory of economic growth to investigate the economic development in Pacific Asian economies. The profound argument of the study is that institutions are very important to explain the economic growth of these countries. Yet, a closer look at his work unveils a more gradation situation. The author showed that variables such as political polarization, political stability and government repression were the political variables affecting growth in these countries. He also explored that political institutional framework is an important factor for explanation of economic growth by restricting individual decisions in their marketplace.

Hall and Jones (1999) postulated one of first empirical research establishing the relation between economic performance and institutions. Social infrastructure is considered as institutional variable which was defined as "the institutions and government policies that determine the economic environment within which individuals accumulate skills, and firms accumulate capital and produce output." They mentioned the relation between the provision of protection to private productive units from confiscatory diversion and institutions. Yielding that a perfect measurement of social infrastructures is not in rehearsal, they choice a proxy gained by pooling two indexes: "an index of government anti-diversion policies" and "an index of openness to international trade". On the other hand, a fundamental basis to measure the institutions was provided in this study and adopted methodology to measure institutional variables was used in many studies to know the relation between institutions and economic performance in many studies later on.

Several studies like Atje and Jovanovic (1993), Levine and Zervos (1998), Thornton (1995), Hondroyiannis et al. (2005), Nieuwerburgh et al. (2006), Enisan and Olufisayo (2009), Boubakari and Jin (2010), Masoud and Hardaker (2012), Miguel et al. (2013), Cojocaru et al. (2014) examined the efficacy of stock market on economic 
growth of countries with contradictory findings. Some of them found a positive relationship between stock market and economic growth while others have negative effect.

These studies reinforce the argument that there is space to explore the joint impact of public spending, institutional quality and stock market development for a developing economy, Pakistan. It is also clear that empirical outcomes are likely to differ from country to country and time to time, even by using same techniques and methods when examining these indicators individually. It can be viewed also from literature that there is hardly any study in our observation which may explore the impact of government spending, quality of institutions and stock market development on economic growth of Pakistan. This study will provide a baseline for further advancement of research and better policy option for policy makers.

\section{METHODS}

By keeping in view the methodology adopted by Madni (2014), following model is derived.

$$
Y=\beta_{0}+\beta_{1} F P t+\beta_{3} I N S T t+\beta_{4} S M t+\beta_{5} Z t \mu
$$

Where Y, FP, INS, SM and $Z$ represent the economic growth, fiscal policy, institutional quality, stock market and control variables respectively.

This study is focused to determine the impact of government spending, stock market and institutional quality simultaneously on economic growth of Pakistan. For this purpose, economic growth is treated as a dependent variable while institutions, stock market and government spending along with control variables are independent variables. The data set of institutional quality is based on the compilation of different institutional measures from ICRG (International Country Risk Guide), organized in twelve clusters namely as Bureaucratic Quality, Democratic Accountability, Ethnic Tension, Rule of Law, Religion in Politics, Military in Politics, Corruption, Government Stability, External Conflict, Internal Conflict, Investment Profile and Socioeconomic Condition. All of these variables range from 0-10. A higher score means higher condition and vice versa. By considering all these variables, an institutional quality index is developed by PCA (Principal Components Analysis). PCA is a statistical technique which uses an orthogonal transformation to alter a group of observations having a possible correlation of variables into an array of uncorrelated linear variables. The time span of data for this part is from 1984-2015.

Stock market capitalization is shares of all domestic listed companies as percentage growth of GDP. Government expenditures are treated as a percentage of GDP to represent the fiscal variables. Economic growth is measured from real economic growth, education is primary and secondary enrolment as percentage of population, trade openness is ratio of sum of exports and imports while investment is considered as private investment as percentage of GDP.

\section{RESULTS AND DISCUSSION}

To find the unit root and order of integration, ADF test is applied to all variables. The results indicate that some variables are stationary at level while others are stationary at first difference. The estimated results of the test are reported in the following Table 3. 
Table 3. Unit root tests results (Augmented Dicky Fuller Test)

\begin{tabular}{lcccc}
\hline \multirow{2}{*}{ Variable } & \multicolumn{3}{c}{ Level } & \multicolumn{1}{c}{$\mathbf{1}^{\text {st }}$ diff } \\
\cline { 2 - 5 } & Intercept & Trend and Intercept & Intercept & Trend and Intercept \\
\hline INST & -1.63 & -1.84 & $-3.84^{*}$ & $-4.47^{*}$ \\
GEXP & -1.87 & -2.38 & $-7.16^{*}$ & $-7.23^{*}$ \\
EDUC & -0.75 & $-4.14^{*}$ & $-4.96^{*}$ & $-5.71^{*}$ \\
OPEN & $-2.31^{* * *}$ & $-2.41^{* * *}$ & $-5.77^{*}$ & $-6.81^{*}$ \\
INVT & -1.58 & -2.27 & $-3.92^{*}$ & $-4.11^{*}$ \\
GDPG & -2.47 & -3.61 & $-4.71^{*}$ & $-5.56^{* *}$ \\
SM & -1.09 & -2.85 & $-2.41^{*}$ & $-4.95^{*}$ \\
\hline
\end{tabular}

Note: *,** and $* * *$ shows significance at $1 \%, 5 \%$ and $10 \%$ level respectively.

If variables have different integrating order, then ARDL approach is appropriate to find the long and short run dynamics of variables.

Now, the unrestricted vector auto regressive model is applied to determine the lag length of variables via Schwartz Bayesian Criterion. The minimum value of Schwartz Bayesian Criterion represents the order of lag length as shown in the following Table 4.

Table 4. Lags defined through VAR-SBC

\begin{tabular}{|c|c|c|c|c|c|c|c|}
\hline Lags & GDPG & SM & GEXP & INST & EDUC & INVT & OPEN \\
\hline 0 & 1.55 & 1.84 & 2.97 & 3.26 & 0.56 & $0.54 *$ & 1.83 \\
\hline 1 & $0.07 *$ & $0.31^{*}$ & $1.39 *$ & 2.73 & $0.16^{*}$ & 1.93 & $1.27 *$ \\
\hline 2 & 0.33 & 0.75 & 2.45 & $1.92 *$ & 0.71 & 2.59 & 1.99 \\
\hline
\end{tabular}

NOTE: * Shows minimum Schwarz SBC.

To find the presence of long run relation between variables, the value of Fstatistics is calculated. The calculated value of F-statistics is 5.34 while the critical Bounds values are at 10\% level of significance (2.035-3.153), at 5\% are (2.365-3.553) and at $1 \%$ are (3.027-4.296) so it indicates the presence of long term relation between variables.

\section{Estimation of long run elasticities}

After finding the existence of long run relationship, ARDL technique is applied to estimate the long run and short run coefficients. The ARDL form of the growth equation will be as follows;

$$
\begin{gathered}
\Delta \mathrm{GDPG}^{-} \alpha_{0}+\sum_{i=0}^{n} \alpha_{1} \Delta \mathrm{GDPG}_{\mathrm{t}-\mathrm{I}}+\sum_{i=0}^{n} \alpha_{2} \Delta \mathrm{GEXP}_{\mathrm{t}-\mathrm{i}}+\sum_{i=0}^{n} \alpha_{3} \Delta \mathrm{SM}_{\mathrm{t}-\mathrm{I}}+\sum_{i=0}^{n} \alpha_{4} \Delta \mathrm{INST}_{\mathrm{t}-\mathrm{i}} \\
+\sum_{i=0}^{n} \alpha_{5} \Delta \mathrm{EDUC}_{\mathrm{t}-\mathrm{i}}+\sum_{i=0}^{n} \alpha_{6} \Delta \mathrm{INVT}_{\mathrm{t}-\mathrm{i}}+\sum_{i=0}^{n} \alpha_{7} \mathrm{OPEN}_{\mathrm{t}-\mathrm{I}}+\beta_{1} \mathrm{GDPG}_{\mathrm{t}-1}+ \\
\beta_{2} \mathrm{GEXP}_{\mathrm{t}-1}+\beta_{3} \mathrm{SM}_{\mathrm{t}-1}+\beta_{4} \mathrm{INST}_{\mathrm{t}-1}+\beta_{5} \mathrm{EDUC}_{\mathrm{t}-1}+\beta_{6} \mathrm{INVT}_{\mathrm{t}-1}+\beta_{7} \mathrm{OPEN}_{\mathrm{t}-1}+\varepsilon_{\mathrm{t}}
\end{gathered}
$$

In this model, government expenditures (GEXP), stock market capitalization (SM), institutions (INST), education (EDUC), private investment (INVT), trade openness (OPEN) are considered as independent variables while GDP growth is a dependent variable. To test the efficiency of data, White heteroscedasticity test, serial correlation LM test, normality test and $\mathrm{ARCH}$ test were applied and output of tests 
indicate that data has not any econometric problem. The estimated results are pasted in the following Table 5 .

Table 5. Estimated long run coefficients for growth equation

\begin{tabular}{lrrrr}
\hline Dependent Variable GDP growth & \multicolumn{4}{c}{ ARDL Technique Order(1,2,1,1,0,1) } \\
\hline Regressors & Coefficients & Std. Error & t-Statistic & Prob. \\
\hline GEXP & $0.27^{* * *}$ & 0.15 & 1.85 & 0.07 \\
INST & $0.33^{*}$ & 0.13 & 2.46 & 0.01 \\
SM & $0.11^{* *}$ & 0.04 & 2.47 & 0.02 \\
EDUC & $0.22^{* * *}$ & 0.13 & 1.77 & 0.08 \\
INVT & $0.27^{* *}$ & 0.14 & 2.12 & 0.04 \\
OPEN & 0.45 & 0.59 & 0.76 & 0.45 \\
\hline
\end{tabular}

$\mathrm{R}^{2}=0.92$

Adjusted $\mathrm{R}^{2}=0.90$

DW-stat $=1.93$

Serial Correlation LM Test $=0.08(0.77)$

ARCH Test $=2.53(0.38)$

White Heteroscedasticity $=0.85(0.48)$

Jarque-Bera Test $=0.44(0.70)$

Note: $* * *$ and $* * *$ shows significance at $1 \%, 5 \%$ and $10 \%$ level of significance respectively.

This study examined the relationship between economic growth, government spending, stock market capitalization and institutions. The estimated results indicate that government spending has significant impact on economic growth of country and 1 percent increase in government spending will lead to economic growth by 0.27 percent. The increased government spending causes to improve the human capital, infrastructure and more facilitation for public that leads to increase the productivity of labor so economic growth is accelerated. It has been revealed that stock market capitalization is significant indicator for economic growth of the county and one unit increase in stock market capitalization would increase the GDP by $0.11 \%$. The estimated result point out that institutional quality is more important than the government spending. The effectiveness of institutions on economic growth of Pakistan is significant and one unit increase in institutional quality will lead to improve the economic growth by 0.33 units. It is evident that with strong and effective institutional framework, people have inclusion in the development process as well as availability of equal opportunities. The efficient judicial and law enforcement mechanism makes it convenient to reduce the transaction costs so the gains from economic activities increase. Education also plays an important role to increase the growth of Pakistan. Findings of empirical investigation reveal that on unit increase in educational level of people will boost the economic growth by 0.22 units. It is evident that literate person are more productive as compared with illiterate persons. In the same way, private investment has a significant and positive impact on economic growth. It indicates that increase in investment increases the productivity and there are more chances of employment so it accelerates the economic growth. The derived results show that trade openness has not significant impact on economic growth. One of the reasons of insignificance of trade openness may be the non-competitive prices of our production sector in international market due to energy crisis and inflation rate of the country while on the other side; our imports are higher than exports so Pakistan is not much beneficiary from free trade policies. 


\section{Error correction representation for the ARDL model of economic growth}

After estimating the long run relationship, we are able to estimate the error correction model for short run dynamics. The ECM form of growth model is following;

$$
\begin{aligned}
\Delta \mathrm{GDPG}= & \alpha_{0}+\sum_{i=0}^{n} \alpha_{1} \Delta \mathrm{GDPG}_{\mathrm{t}-\mathrm{I}}+\sum_{i=0}^{n} \alpha_{2} \Delta \mathrm{INST}_{\mathrm{t}-\mathrm{i}}+\sum_{i=0}^{n} \alpha_{3} \Delta \mathrm{SM}_{\mathrm{t}-\mathrm{i}} \sum_{i=0}^{n} \alpha \Delta \Delta \mathrm{EDUC}_{\mathrm{t}-\mathrm{i}} \\
& +\sum_{i=0}^{n} \alpha_{5} \Delta \mathrm{INVT}_{\mathrm{t}-\mathrm{i}}+\sum_{i=0}^{n} \alpha_{6} \Delta \mathrm{OPEN}_{\mathrm{t}-\mathrm{i}}+\sum_{i=0}^{n} \alpha_{7} \Delta \mathrm{GEXP}_{\mathrm{t}-\mathrm{i}}+\mathrm{ECM}_{\mathrm{t}-1}+\varepsilon_{\mathrm{t}}
\end{aligned}
$$

Here $\mathrm{ECM}_{\mathrm{t}-1}$ is the adjustment parameter. It shows the speed of adjustment while the other parameters represent the short run coefficients reported in the Table 6 .

Table 6. Estimated short run coefficients for growth equation

\begin{tabular}{lrrrr}
\hline Dependent Variable GDP Growth & \multicolumn{4}{c}{ ARDL Technique Order $(1,2,1,1,0,1)$} \\
\hline Regressors & Coefficients & Std. Error & t-Statistic & Prob. \\
\hline$\Delta$ GEXP & 0.27 & 0.15 & 1.75 & 0.09 \\
$\Delta$ INST & 0.12 & 0.13 & 0.98 & 0.34 \\
$\Delta$ SM & 0.33 & 0.13 & 2.46 & 0.01 \\
$\Delta$ EDUC & 0.20 & 0.41 & 0.49 & 0.63 \\
$\Delta$ INVT & 0.15 & 0.085 & 1.75 & 0.09 \\
$\Delta$ OPEN & 0.21 & 0.44 & 0.48 & 0.61 \\
ECM $_{\mathrm{t}-1}$ & $-0.28^{* *}$ & -0.073 & 2.02 & 0.001 \\
\hline
\end{tabular}

$\mathrm{R}^{2}=0.93$

Adjusted $\mathrm{R}^{2}=0.91$

DW-stat $=1.92$

Serial Correlation LM Test $=0.15(0.66)$

ARCH Test $=0.34(0.48)$

White Heteroscedasticity $=0.16(0.38)$

Jarque-Bera Test $=0.87(0.54)$

Note: $*$ and $* *$ shows significance at $1 \%$ and $5 \%$ level of significance.

The estimated lagged error correction term $\mathrm{ECM}_{\mathrm{t}-1}$ is negative and significant. The negative and significant error correction term indicates that there is a long run relationship among the variables. The feedback coefficient is -0.28 . It indicates that 28 percent disequilibrium is corrected in the short run. In short run, public spending and private investment is significant for economic growth while institutional framework, education and trade openness are not significant in the short run.

\section{CONCLUSIONS AND POLICY IMPLICATIONS}

This study highlighted that institutional quality, stock market development and government spending are necessary to promote the economic growth and living standard of the country. In this analysis, a number of competing hypotheses, on what contributes to Pakistan's economic performance, have been tested using econometric model. This study is a first attempt to explore the factors of economic growth in the context of institutional quality, stock market development and fiscal policy in Pakistan. There is hardly any study that investigated the impact of institutional quality and public spending simultaneously for Pakistan.

This study used the time series data covering the time span from 1984-2016 and econometric techniques (ARDL, stability tests) were applied. The empirical findings come up with following conclusions. 
The empirical analysis suggests that the economic growth depends fundamentally on government expenditures, stock market and institutional quality. Government spending is contributing to improve the growth very little. The growth rate of the economy may be enhanced by productive public spending (public welfare oriented spending) as highlighted by Madni (2013). The government spending builds a relation of confidence between state and public due to the effective utilization of public taxation. Productive public spending causes to increase the confidence of people on public institutions and high quality institutions lead to boost the economic growth. So institutional quality and public spending are intermingled to explain the growth of an economy. If government spending is not public oriented, the people lose their confidence on state along with institutions of state and prefer to be more corrupt, which slows down the growth of country. In case of Pakistan, it is dire need to improve the efficiency of public spending because a major portion of public spending going to be preyed of corruption. According to report of transparency international, in the Corruption Perception Index (PCI), Pakistan stands at $117^{\text {th }}$ position out of while Somalia and North Korea remained at $167^{\text {th }}$ position that reflects highest level of corruption in the world. The Corruption Perception Index (CPI) ranks countries and territories based on how corrupt their public sector is perceived to be. The public oriented and corruption free spending of government may boost the economic growth as well as institutional quality of the country. The institutional indicators of Pakistan are going to be improved but there is still an ample space for their improvements. The encouragement of stock market in presence of quality institutions will certainly contribute to faster economic growth. The Pakistan Stock Exchange is emerging as one of the biggest stock markets of the world and its fruits can be ripen with effective government policies in presence of strong institutions.

By concluding, government spending fosters good institutions and high quality institutional framework is expected to be developed in equitable and open economies, with a sound fiscal contract in an educated population leading to enhance the confidence of investors in financial markets.. If these conditions are met, then it is possible to attain remarkable and sustained economic growth. Overall, results propose that variables leading to explain the economic growth are in reach of government. Although it is not an easy task but there is room for policies aimed at improving the growth.

\section{REFERENCES}

Alesina, A. (1998). The Political Economy of High and Low Growth, in Annual World Bank Conference on Development Economics, Washington DC: World Bank.

Atje, R., Jovanovic, B. (1993). Stock Markets and Development. European Economic Review, 37, 632-640.

Barro, R. J. (1990). Government Spending in a Simple Model of Endogenous Growth. Journal of Political Economy, 98(5): 103-125.

Barro, R. J. and Sala-i-Martin, X. (1992). Public Finance in Models of Economic Growth. Review of Economic Studies, 59: 645-661.

Benos, N. (2009). Fiscal Policy and Economic growth: Empirical Evidence from EU Countries. Working Paper, University of Loannina, Greece.

Bleaney, M. F., Gemmel, N., Kneller, R. (2001). Testing the Endogenous Growth Model: Public Expenditure, Taxation, and Growth over the Long Run. Canadian Journal of Economics 34(1): 36-57. 
Boubakari, A., Jin, D. (2010). The Role of Stock Market Development in Economic Growth: Evidence from some Euro next countries. International Journal of Financial Research, 1(1), 14-20.

Christie, A. L. (2011). Essays on Fiscal Policy and Economic Growth. Ph.D. Dissertation, Georgia State University, Economics Department.

Cojocaru, L., Hoffman, S.D., Miller, J.B. (2014). Financial System Development and Economic Growth in Transition Economies: New Empirical Evidence from the CEE and CIS countries. Working Paper Series, University of Delaware. Available from: https://www.sites. udel.edu/saulhoffman/files/2014/03/FinancialDevelopmentGrowth- FINAL-1vugriz.pdf.

Enisan, A.A., Olufisayo, A.O. (2009). Stock Market Development and Economic Growth: Evidence from Seven Sub-Sahara African Countries. Journal of Economics and Business, 61, 162-171.

Feng, Y. (2003). Democracy, Governance and Economic Performance: Theory and Evidence. Cambridge: MA, MIT Press.

Glaeser, (2004). Do Institutions Cause Growth? Journal of Economic Growth, 9(3): 271-303.

Goldsmith, R.W. (1969). Financial Structure and Development. New Haven, CT: Yale University Press.

Hall, R. E., Jones, C. (1999). Why Do Some Countries Produce So Much More Output Per Worker Than Others? Quarterly Journal of Economics, 114: 83-116.

Hassan, M. T. (2002). Governance and Poverty in Pakistan. MIMAP Technical Series, No.13. Pakistan Institute of Development Economics, Islamabad.

Hondroyiannis, G., Lolos, S., Papapetrou, E. (2005). Financial Markets and Economic Growth in Greece, 1986-1999. International Financial Markets, Institutions and Money, 15, 173-188.

Ibrahim, O. A., Gadir, S. E. M. (2015). Motives and Determinants of FDI: A VECM Analysis for Oman. Global Business Review, 16(6): 936-946.

Kakar, Z. K. (2011). Impact of Fiscal Variables on Economic Development of Pakistan. Romanian Journal of Fiscal Policy, 2(2):1-10.

Knack, S., Keefer, P. (1995). Institutions and Economic Performance: Cross-Country Tests Using Alternative Institutional Measures. Economics and Politics, 7(3): 207-227.

Kneller, R., Bleaney, M. F., Gemmel, N. (1999). Fiscal Policy and Growth: Evidence from OECD Countries. Journal of Public Economics, 74: 171-190.

Levine, R. (1997). Financial Development and Economic Growth: Views and Agenda. Journal of Economic Literature, XXXV, 688-726.

Levine, R., Zervos, S. (1998). Stock Markets, Banks and Economic Growth. American Economic Review, 88, 537-557.

Madni G. R. (2013), Instrumental Effects of Fiscal Policy for Pakistan Economy. The Romanian Economic Journal, 50: 27-49.

Madni, G. R. (2014). Taxation, Fiscal Deficit and Inflation in Pakistan. The Romanian Economic Journal, 53: 41-60.

Madni, G. R. (2017). Economic Growth in Context of Institutions and Fiscal Policy. Pakistan Economic and Social Review, 55 (1): 79-98.

Masoud, N., Hardaker, G. (2012). The Impact of Financial Development on Economic Growth. Studies in Economics and Finance, 29(3), 148-173.

Mauro, P. (1995). Corruption and Growth. Quarterly Journal of Economics, 110:681712. Pesaran, M., Shin, Y. (1999). An Autoregressive Distributed Lag Modeling 
Approach to Cointegration Analysis. Chapter 11, Cambridge University Press Cambridge.

McKinnon, R.I. (1973). Money and Capital in Economic Development. Washington, DC: Brooking Institution Press.

Miguel, M.L., Fuinhas, J.A., Marques, A.C. (2013). Does the Stock Market Cause Economic Growth? Portuguese Evidence of Economic Regime Change. Economic Modeling, 32, 316-324.

Nieuwerburgh, S., Buelens, F., Cuyvers, L. (2006). Stock Market Development and Economic Growth in Belgium. Explorations in Economic History, 43, 13-38.

North, D. C. (1990). Institutions, Institutional Change and Economic Performance. Cambridge, Cambridge University Press.

Ramadhan, A. A. et al. (2016). Does Political Stability Accelerate Economic Growth in Tanzania? A Time Series Analysis. Global Business Review, 17(5): 1026-1036

Rebelo, S. (1991). Long-Run Policy Analysis and Long-Run Growth. Journal of Political Economics, 99(3): 500-521.

Schumpeter, J.A. (1911). The Theory of Economic Development. Cambridge, MA: Harvard University Press.

Shaw, E.S. (1973). Financial Deepening in Economic Development. New York: Oxford University Press.

Thornton, J. (1995). Financial Deepening and Economic Growth in Developing Countries. International Economics, 48(3), 423-430. 